\title{
CONTESTATIONS OVER MALAYSIAN CITIZENSHIP AND THE PRELIMINARY CASE FOR RECOGNISING THE STATELESS BAJAU LAUT COMMUNITY
}

\author{
Sanen Marshall, Saidatul Nornis Hj. Mahali \& Junaidah Januin \\ Centre for the Promotion of Knowledge and Language Learning, \\ Universiti Malaysia Sabah \\ (sanenmarshall@gmail.com) \\ DOI: https://doi.org/10.22452/bri.sp2019no1.6
}

\begin{abstract}
The discussion below revisits the perennial problem of illegal immigration in the Malaysian state of Sabah that has for more than a decade now stood as an internationally recognised case study of how countries sometimes prefer illegal immigrants over their own citizens. This article therefore discusses the process by which the Malaysian Federal Government acceded to public requests for the institution of an inquiry into the issue of illegally obtained citizenship in Sabah. Important questions remain unanswered, however, leading to the incredulity of researchers and activists. This situation has been further exacerbated by the 2013 intrusion of a group of armed southern Filipinos into a coastal village in eastern Sabah. The article therefore goes on to discuss how the ensuing conflict between these vigilantes and the Malaysian Government impacted upon and, indeed, further weakened the foundations of Malaysian nationality. Under the current circumstances, do not even local officials now believe that at least some of these undocumented persons possess the right to residence or even citizenship in Sabah, Malaysia? We present a preliminary discussion of the case for citizenship for a de jure stateless community known as the Bajau Laut.
\end{abstract}

Keywords: citizenship, stateless, Bajau Laut, illegal immigration, security

\section{Introduction}

The East Malaysian state of Sabah has emerged as a major case study in the theory of illegal immigrants and citizenship. Sadiq (2005) in his seminal work entitled "When States Prefer Non-Citizens Over Citizens: Conflict Over Illegal Immigration into Malaysia" cites the scandalous case of Malaysia being a country that gave citizenship to foreigners in order to win the state elections in Sabah. The numbers are 
mind-boggling. Beginning in the 1970s, the state has come to be flooded with hundreds of thousands of Filipino refugees. Sabah recorded a 390\% increase in population from 1970 to 2010; that is from 636,431 to 2,483,609 ("Population Growth", 2012). Sabah has thus been identified as the place of the "biggest concentration of Filipino illegals in any part of the world" (Sadiq, 2005). The more worrying problem is that many illegal immigrants from the Philippines and other countries have already been given Malaysian citizenship in Sabah. The population of illegal immigrants and foreign-workers originating from the Philippines and Indonesia "simply exceeds one-third of Sabah's population" (Hassan, Idris, \& Ahmad, 2010, p. 94). Because of the relatively small local population in Sabah, the influx of such a huge number of foreigners is more acutely felt and is deeply resented. The fact that many of these foreigners have in the past been given citizenship has therefore been a constant political issue over the decades. This is because it means that illegal immigrants could cast their votes in such critical instances as the fiercely contested Sabah state elections of 1994. On that occasion the indigenous Sabah political party that won by a slim majority saw its government collapse after only two weeks in power due to post-electoral manipulations. This event led to the Federal government's ruling party (which is actually headquartered in West Malaysia) take over the administration this East Malaysian state for the first time in Sabah's history.

To date, there has been no admission of responsibility by either the thenserving Federal or State politicians for the fact that so many illegal immigrants managed to obtain Malaysian citizenship and therefore voting rights. However, because of the colossal scale of the illegal immigrant problem and the serious ramifications for electoral politics, there has been in recent times a huge groundswell of support for Sabah state politicians who brandish the issue against their Federal counterparts. Federal-State relations in Malaysia has been historically full of intrigue, foot-dragging and shenanigans on both sides. It is rarely possible to tell how serious either side is in pursuing a certain agenda, except that on the issue of illegal immigrants both Federal and State politicians are well-aware that it strikes a chord with a very disenchanted electorate in the State. These anti-illegal immigrant sentiments have to be pandered to, to a greater or lesser extent.

The situation involves on the one hand an apathetic but legitimate Muslim segment of the electorate that traditionally did not worry too much about illegal immigrants, who were in any case overwhelmingly Muslim. On the other hand, the situation involves an incensed, disenfranchised and, of course, legitimate nonMuslim electorate. So it was probably not much of a surprise that after years of stalling and side-stepping the issue, the Federal Government of Malaysia under the leadership of then-Prime Minister Najib Abdul Razak agreed to a fact finding mission called the Royal Commission of Inquiry on Illegal Immigrants (RCI). It was launched on 11 August 2012. The circumstances under which the RCI was finally announced - Najib had promised to do it a few months earlier - were almost 
certainly due to the ruling political party of the Federation not wanting to court the possibility of a voter backlash from the disenchanted non-Muslim segment of the Sabah electorate.

\section{The Inquiry and the Intrusion}

The RCI was formed on the assumption that the Sabah public would finally get the answers to the long unresolved concerns about illegal immigrants. However, as Lai (Lai, 2015) noted, almost tongue-in-cheek, that "the RCI found inconclusive evidence suggesting the existence of 'Project $\mathrm{IC}^{\prime}$ ', although approximately half a million foreigners in Sabah were found to have been issued the MyKad to date" ('Projek IC' was an alleged Federal government-run clandestine programme to give illegal immigrants national identity cards (ICs), the latest version of which was the highersecurity MyKad) (p. 70). Therefore, in the wake of the inconclusiveness of the RCI report, legitimate citizens of the state of Sabah, Malaysia have been left to draw their own conclusions. What actually happened to cause their state to be flooded with unlawful citizens?

One such conclusion was drawn in locally produced documentary called Sindiket, which alluded to the likelihood that the giving out of ICs was indeed a Federal-level initiative to counter the demographic-majority-cum-political-clout of the "Christian" bumiputra (indigenous persons) by bolstering the numbers of the "Muslim/Malay" bumiputra constituency by infusing the latter with illegal immigrants from the southern Philippines (Andan \& Atama, 2015). The documentary was 'banned' from screening at the Kota Kinabalu International Film Festival (personal communication with J. Day, 13 July 2016). That same year another locally produced film called Dream to Fly won an award at the Kota Kinabalu International Film Festival. It featured the story of a 10-year old stateless boy whose "guardian resorts to purchasing a [birth certificate] on the black market, just so the boy can go to school". When interviewed, the filmmaker attested that "[t]he buying and selling of birth certificates in Sabah is a sensitive subject. Everyone knows about it but turns a blind eye" (Reddy, 2016, p. 10).

The word on the street therefore - if we can take these locally produced films to be a reflection of what people already know or are thinking about - is that there is both a push and a pull factor driving the IC-industry. Ever desperate for citizenship in a comparatively prosperous land, migrants from the largely Muslim southern Philippines are more than willing to latch on to any Government initiatives (as the first film implies) to provide them with legitimate voter identities.

The outcry against illegal immigrants has therefore today reached fever pitch. Public sentiment has gone way beyond grievances over social disintegration and political contests. Today's discussion about illegal immigration is also about the very security of the state of Sabah. 
On 12 February 2013, with the RCI investigations still at an early stage, a 200strong group of southern Filipinos constituting the so-called Royal Sulu Army made an intrusion into a remote village on the eastern coast of Sabah called $\mathrm{Kg}$. Tanduo. The group was led by one Agbimuddin Kiram. He was the brother of the self-styled Sultan Jamalul Kiram III, a claimant to the long-defunct throne of the Sultan of Sulu in the southern Philippines. The Sulu Sultanate, which Agbimuddin claimed to represent, once exercised suzerainty over the east coast of Sabah. The Malaysian government as the successor to the government of British North Borneo still pays cession money annually to the claimants of the throne of the defunct Sulu Sultanate for the 1881 British lease of Sabah contracted with the then-ruling Sultan Jamalul Kiram ("Malaysia Pays Cession Money", 2013). This attack, therefore, unlike previous attacks emanating from the southern Philippines, could not simply be dismissed as an act of piracy.

\section{Political Significance}

Reviewing the incident, Lai (2015) noted that "Sabah's affable sense of security and confidence came to a dramatic halt following a rare 'foreign' intrusion in February 2013" wherein the forces under the leadership of Agbimuddin Kiram were seen to be "breaching the state's far eastern borders to assert what they allegedly claimed to be their unresolved territorial rights in North Borneo [Sabah]". In this sense, it was not a 'rare' intrusion but the only intrusion of its kind. Unlike previous pirate-type intrusions from the southern Philippines into Sabah, this one was clearly a political act that will haunt Malaysia for decades to come. A group of southern Filipinos operating under the auspices of a claimant to the throne of the historical Sulu Sultanate forcibly take over a piece of land in the neighbouring Malaysian state of Sabah, over which that Sultanate had historically exercised the power of suzerainty and they refused to leave even in the face of certain death. There has never been an incident like this involving non-state actors on Malaysian soil. Moreover, Lai (2015) rightly appears to be somewhat skeptical of the 'foreign' character of the intrusion, whose intrusion for Nyers (2008) might even be termed an 'act of citizenship,' when he writes:

Politics occurs during those moments when those who 'do not count', who have 'no part' in the recognized social order, make a claim to be counted. These claims appear as an interruption of the established speaking order which elevates citizenship to holding a near monopoly of speech acts. ( $p$. 164)

Formal aspects of citizenship, as Isin (2008, p. 37) argues, tend to 'arrive at the scene too late because their actors ... are already produced.... $:$ here then was a group of southern Filipinos operating in Sabah as it were under the orders of the heir to the 
$19^{\text {th }}$ century suzerain. What ensued was a stand-off between the Royal Malaysian Army and the 'Royal Sulu Army' lasting for three weeks. Militarily, the besieged intruders stood no chance against the Royal Malaysian Army. However, it was during this stand-off that Sultan Jamalul Kiram III made a memorable political claim. He declared that there was no reason for his followers to return to the Philippines since "Sabah is our home" ("Sabah is Our Home", 2013). The 'speech act' of declaring the intruders to be legitimate residents of the Malaysian state of Sabah coupled with the act of citizenship in occupying a piece of contested territory in the face of certain death is what national narratives are all about! This was a monumental development whose significance is yet to be recognised by Malaysian and Filipino academics. The incident taken as a whole was thus a definable moment in Malaysia-Philippines history.

\section{Malaysia's Citizenship Undermined}

No amount of subsequent countermanding speech acts on the part of the Malaysian Government or even the bombing campaign conducted by the Royal Malaysian Air Force could dismiss the fact that the newly recognised enemy was once regarded as Sabah's own: is the leader of the 2013 Tanduo intrusion, Agbimuddin Kiram, a former Sabah state official? News reports certainly seem to support that conclusion. Sometime after the intrusion, it was reported by a leading Malaysia daily that "Agbimuddin... was a former assistant district officer of [the district of] Kudat, Sabah in the early 1970s" ("Sulu Leader of Lahad Datu", 2015). Neither RCI nor the formation of Eastern Security Command (ESSCOM) in the wake of the Tanduo intrusion has helped to shed any light on this and other such scandalous reports appearing in the local press.

Such reports bring up outrageous questions concerning the true nature of Malaysian citizenship. It is now with some incredulity that Malaysians must regard words of then Deputy Home Minister Datuk Wira Abu Seman Yusory who declared that "citizenship is not the people's absolute right or automatically given but is a special privilege" ("Citizenship is a Special Privilege", 2012). Three years later, Malaysia's National Registration Department itself was echoing this stand by "beg[ging] to differ that Malaysian citizenship is a matter of human right, but [is instead] a privilege awarded by the Government" ("Citizenship a Privilege", 2015). The 1970s refugees from the southern Philippines (now Malaysian citizens) seemed to have obtained this 'privilege' with ridiculous ease. Sadiq (2009) of course concurs that citizenship is in theory a privilege when he notes as follows:

According to traditional scholarship, citizenship is a privilege...since acquiring citizenship status opens the path to many safeguarded citizenship rights, all of which allow an individual a voice in the political governance.... 
citizens...can be trusted to hold public office...for the protection of the state...national interest is safe in their hands...this is why citizenship is a privilege: only the selected few share in it. (p. 19)

However, the stark reality facing Malaysia is that 500,000 illegal immigrants, many of them southern Filipinos, have acquired citizenship in a country of just 20 to 30 million people. And when one of these southern Filipinos, after previously assuming a local State Government position, returns some decades later at the head of a group of armed Sulu nationalists, we can safely dispense with the traditional view of citizenship as a privilege.

\section{Knowing One's Own Citizens}

In January 2014, the Malaysian government declared that there were about 300,000 illegal immigrants in Malaysia of which it was said that they 'cannot be repatriated'. A Deputy Home Minister claimed that "[a]lthough the Government knew their countries of origin, the countries required identification documents to prove citizenship". He added that "[w]e want illegal immigrants to be repatriated as soon as possible as they are a burden to us. Every day we have to provide food and healthcare for these people" ("Government Stuck with 300,000 Illegals", 2014). If the Malaysian government was providing these illegal immigrants with both healthcare and food, it is quite likely that the some of these 300,000 persons were being held in detention centres at that time.

By 2016, one of the culprit 'countries of origin' and one of the Malaysian states playing host to at least a portion of the aforementioned 300,000 illegal immigrants could be identified from news reports. No surprises here. The country was none other than the Philippines and the Malaysian state was none other than Sabah. The local Sabah press then reported that increased cooperation by the Philippines Embassy has resulted in an increase in the deportations of its nationals from Sabah lately.' In the report, National Security Council of Sabah Secretary Rodzi $\mathrm{Md}$. Saad gave out that " $[\mathrm{t}]$ his year we achieved another milestone positive development when a team from the embassy made the initiative to come to the temporary detention centres here to issue travel documents....". Philippine embassy officials had reportedly "inspected the detainees at the detention centres before confirming their citizenship and issuing them the documents" ("More Deported with Cooperation", 2016).

The two news reports taken together would at face value seem to vindicate the claim that the Malaysian government today truly knows the countries of origin to which these illegal immigrants belong.

However, if the Malaysian Federal government, imbued as it is with diplomatic and consular authority, needed a long time to convince the Philippines 
Government of the need to receive the deportation of their 'citizens' back 'home', it appears that some local Sabah community leaders are even less convinced that these undocumented persons are Filipinos. In July 2015, the press reported of ESSCOM deputy director of intelligence ACP Justin Hashim that "ESSCOM regrets that some village heads and Village Security and Development Committee (JKKK) chairmen did not report the presence of illegal immigrants in their areas". He was further quoted as saying "ESSCOM has told village heads and JKKK to report the presence of illegal immigrants but when we conducted integrated operations, many illegals were arrested for not having legal identification documents". Justin added that "[ $t]$ he premises where the illegal immigrants were arrested were not far from the homes of village heads or JKKK chairmen" ("Some Village Heads", 2015). Obviously, some local community leaders of East Coast Sabah were not keen on playing the assigned role of 'eyes and ears' of ESSCOM in this matter. At the time of the press report, ESSCOM claimed it did not know the cause of their negligence.

\section{The Bajau Laut, A Nomadic Society}

In fact, all we have to do is look back to the RCI proceedings to see what one or two village heads from East Coast Sabah were telling the Commission. During the proceedings, the press reported the case of "a village chief" from East Coast Sabah who "said that the government should take into consideration that the sea gypsies, Palauh, have been residing in the waters off Sabah over the centuries..." and that "it was only fair if the government recognized their rights as native settlers, or at least provide them with proper documentation to show their identities" ("RCI Witness Urges Recognition", 2013). The chief resided in one of the villages long-known to be an ancestral habitation of some strand-dwelling Bajau Laut or Pala'u. These had come ashore decades ago at a village known as Bangau-Bangau. Bangau-Bangau was the fieldwork location for Clifford Sather's (1997) seminal work entitled The Bajau Laut: Adaptation, History, and Fate in a Maritime Fishing Society of Southeastern Sabah.

The merit of claims to citizenship therefore lies in the historical circumstances of each case. The case of the Bajau Laut is predicated upon their condition of de jure statelessness, being longstanding interlopers between the big islands of Borneo and Mindanao. The case of the Bajau Laut (also known as Pala'u or even Sama Dilaut) is likewise a case of an entire people who have historically and currently behaved like they belong to both the islands of Sabah and the islands of the Sulu Archipelago (Philippines). The total numbers of the Bajau Laut are difficult to establish because they belong to a larger ethnolinguistic community known as the Sama-Bajau. This community spans both the Philippines and Sabah.

Pallesen (1985) lists 'Sama Dilaut' among several groups of the Sama-Bajau language family found in the Philippines whose total numbers in year 2000 are said to be "at least 209,000" (Social Technology Bureau, 2014, p. 2). In Sabah, 2005 census 
data reports Sama-Bajau numbers to be 343,178 (Hj. Mahali, 2012, p. 3). And yet, despite their numbers, the Sama-Bajau languages do not sub-group with any of the major Philippines or Sabah language languages. A study in historical linguistics by Blust (2007) interestingly traced the origins of the Sama-Bajau languages to the Barito basin in southern Borneo.

Many Sama-Bajau groups have retained their sea-faring culture. The Bajau Laut are unique in the sense of actually living or having lived in boats. Saidatul Nornis Hj. Mahali (2013, p. 89) therefore suggests the exonym 'Palaut', which in Malay world means sea-farer, as the origin of the term Pala'u. Ismail Ali, on the other hand, who writes about the Sabah-based Bajau Laut as mainly concentrated in the Semporna district gives an estimate of their numbers as being between 5,000-7,000 (Ali, 2013, p. 228). This is somewhat of an increase when compared to Sather (1997, p. $3)$, who once gave the total numbers of those 'who remain permanently boatdwelling' as 'rapidly declining and is probably fewer than 5,000 in Malaysia, Philippines and Indonesia.' Writing at that time with specific regard to the Semporna-based Bajau Laut, Sather notes that

In the Semporna district, fewer than 200 Bajau Laut continue to live in boats, most of them newcomers from the Tawitawi island group of southern Sulu, while the population of settled Bajau Laut exceeds 3,500.

Because of their nomadic nature, as noted in Sather's comment above, the issue of the Bajau Laut is currently one of undocumented residency or even illegal immigrantion. As such, the contemporary politics of indigenous Sabahans versus illegal Filipino immigrants is never far from following hard upon the heels of such cases.

In 2014, the Sabah KadazanDusun Murut Welfare and Education Assocation (a non-governmental organisation of some sort) called for Universiti Malaysia Sabah to carry out a detailed study on the demographics of the Semporna Bajau Laut. The term 'KadazanDusut Murut' or KDM is political short-hand for the traditionally nonMuslim, indigenous segment of the Sabah electorate. In this case, the aforementioned NGO feared the "infiltration by Pala' $u$ of a neighbouring country into the local community" ("Proposal for UMS Study", 2014). Echoing this sentiment, in February 2015, the commander of ESSCOM warned the Semporna Bajau Laut community against allowing themselves to be "exploited or to collude with enemies, especially cross-border criminals" (Toyos, 2015). In March 2015, ESSCOM undertook a study to determine the actual numbers of the stateless Bajau Laut occupying three islands in the Semporna district. These three islands were determined to have the largest concentration of Bajau Laut residents. The residents were pre-emptively advised "not to panic or get worried with the presence of security forces because the census does not involve any arrest operation for illegal immigrants like those done in urban areas of Esszone" ("Esscom Study on Pala'u Community", 2015). 


\section{The Bajau Laut in History}

The concerns of the traditionally non-Muslim, indigenous segment of the Sabah electorate and the concerns of the Eastern Security Command (ESSCOM) with regard to the possible 'infiltration' and 'collusion' of stateless Bajau Laut with their Philippines compatriots are legitimate concerns for those who still believe in formal notions of citizenship. Nevertheless, this it is important to stress that there are some Bajau Laut residing in Malaysian waters who are quitely descendants of those earliest sea-faring communities who once lived off the coast of Sabah. They were born in Sabah, not in the Philippines.

Sather (1997) quoting Dewall notes that this ethnic group had been observed way back in 1839 to inhabit the Semporna island of Denawan and indeed "the islands of the northeastern coast of Borneo" (p. 30). The British North Borneo Company also noted their presence in Sabah some forty years later. The northeastern coast of Borneo or East Coast Sabah is where the British North Borneo Company found them as the following report indicates:

The Bajows or Sea Gypsies are a curious wandering irresponsible sort of race, rather low down in the scale of humanity, living almost entirely in families in boats ..... Not caring to store up property, and rarely troubling themselves as to where next week's meals are to come from, they pick up a precarious livelihood, along the shore line, by catching fish, finding see slugs [sic] and turtle eggs, spearing sharks, and so forth....They lead a wild free roving life in the open air, untroubled by any care or thought for the morrow. (Company Officer, 1886, p. 221)

The above-quoted reports prove their presence in Sabah, although their description is hardly complimentary. It is perhaps for this reason that the labelling of this community has been a sensitive subject, given their historical treatment. While the terms Bajau Laut (Malaysia) and Sama Dilaut (Philippines) are generally accepted, some academics prefer to dispense with the term Pala'u altogether, claiming that 'it is pejorative' (Brunt, 2016, p. 4). It is perhaps pejorative in some localities in the southern Philippines and in the Semporna district. However, there remain many people of this ethnicity who identify themselves by this name. Contemporary rejection of the term in specific communities is most likely predicated the historical association of the label with the structures of ethnic stratification.

Abd. Rahim Md. Saffie \& Ramzah Dambul (2012, p. 26) suggest that the issue of the perjorativeness of term Pala' $u$ was in fact more of an issue in the past that it is today. They allude to periods in the 1980s and the 1990s when the term Pala'u "reflected their lowly status within the ethnic hierarchy of the Philippines". This ethnic hierarchy is quite likely the one that might be inferred from Arong's 
discussion on the labelling of the Sama-Bajau in relation to whether the community remained (1) houseboat dwellers; established (2) houses on the strand; or moved (3) completely ashore (Arong, 1962, p. 136). This historical situation quite likely brought about the prejudices of land-dwellers against sea-dwellers, which we continue to witness today. It is a situation that artificially delimits the large, structured societies of land-dwellers at the top of the social hierarchy from the small-scale, loosely configured societies of sea-dwellers at the bottom.

This residential situation, first theorised among the Philippines Bajau Laut, is however not a fixed social situation but a fluid one. It has been subject to historical change, as is partly observed by yet another British North Borneo Company officer reporting on a community of Semporna Bajau in the early $20^{\text {th }}$ century.

Since the latter part of the year the Simporna [sic] Bajaus have shewn an inclination to remove from their old houses over the sea to new ones on the shore....they are however only planting "ubi kayu" and keeping fowls more extensively than previously. (Company Officer, 1914, p. 1)

For those who have left their houseboats and removed to pile-houses or the shore, the term Pala'u may be pejorative. Many of these have undoubtedly attained citizenship/permanent residency and no longer migrate between islands. Nor do they still live in houseboats. Some of these persons may indeed no longer wish to identified as 'Pala'u.'

\section{Conclusion}

The Bajau Laut provide us with the most compelling evidence that the Malaysian nation and the Malaysian state are not congruous. When we have a case of an ethnic group that has typically straddled the international sea borders of Malaysia and the Philippines, it is difficult to argue that from the perpective of hard and fast categories of citizenship and nationality. The legally enforced borders by government agencies such as Eastern Sabah Security Command (ESSCOM) do not just uphold Malaysian territorial sovereignty. They limit any futher eastward expansion of the Malaysian nation. This is done in the hope that peoples' alliances and loyalties do not extend into the confines of other states and vice versa. Preventing such incongruences is primary challenge of nationalism such as has been discussed by Gellner (1983) and others theorists.

It is nevertheless true that many nations and states, even those in the heart of modern Europe, face a similar problem. What is surprising in the Malaysian case is the body of evidence that has emerged pointing to the fact that the Malaysian state in Sabah has willfully chosen undermine its own concept of citizenship as a privilege. The Malaysian appears to have wilfully courted peoples whose loyalties do not necessarily lie within the borders of Malaysia. The charge of deliberately infusing the 
territory of Sabah with hundreds of thousands unlawful citizens seems to have been affirmed rather than to have been disproved by the inconclusive verdict drawn by the Royal Commission of Inquiry for Illegal Immigrants in Sabah (RCI). Sabah and/or Malaysia has allowed into the state peoples whose loyalty not only cannot be counted upon but whose tendency is sometimes to act against the interests of the state in favour of a foreign political entity.

At the same time, the Malaysian state continues to argue for the exclusive right to bestow the 'privilege' of citizenship, which it claims cannot be bestowed on the basis of human rights or humanitarian grounds. This situation now adversely impacts upon the right of the Bajau Laut as a de jure stateless communitiy to claim citizenship in Malaysia. Several of their members have already been arrested, detained and deported by the Malaysian authorities in Sabah over the course of the last few years since the watershed moment of 12 February 2013 in Tanduo on East Coast Sabah.

Certain village officials, however, in places like the traditional Bajau Laut village of Bangau Bangau seem to be following their own conscience with regards to whom they perceive to be legitimate residents. At the same time, minority elements within the non-Muslim indigenous segment of the Sabah electorate seem to have tentatively recognised the legitimate case of the Semporna Bajau Laut to reside in Sabah waters, if not to actually become citizens. There is perhaps yet hope, despite the general anti-immigrant sentiment, that at some point in the future this magnanimous attitute will allow for the lawful recognition of stateless persons like those of the Bajau Laut community. Professor Dr. Yahaya Ibrahim, the deputy head of the erstwhile National Professor's Council's Historical seems to be in no doubt. He says, "They are our citizens. Even though their race and ancestry are unknown, they have been living in our waters for a very long time. Why must we deny them their rights?" (Bernama, 2015, p. 14).

\section{References}

Abd. Rahim, M. S., \& R. Dambul. (2012). Identiti Etnik Bajau Pantai Timur. In R. Dambul, M. S. Abd. Rahim, \& S. Osman (Eds.), Bajau Pantai Timur (pp. 7-30). Kuala Lumpur: ITMB.

Ali, I. (2013). Sosioekonomi Dan Status Kewarganegaraan Komuniti Bajau Laut. In S.

N. Hj. Mahali (Ed.), Nilai Dan Norma Masyarakat Di Sabah (pp. 225-246). Kota Kinabalu: Penerbit Universiti Malaysia Sabah.

Andan, N., \& Atama. (2015). Sindiket. Freedom Film Network. Retrieved 24 January 2018, from https://freedomfilm.my/video/2015-sindiket/

Arong, J. R. (1962). The Badjaw of Sulu. Philippines Sociological Review, 10(3/4), 134147. 
Bernama. (2015, 17 June). Change in Sight for Sabah's 'stateless' Sea Gypsies? Daily Express, p. 14.

Blust, R. (2007). The Linguistic Position of Sama-Bajaw. Studies in Philippine Languages and Cultures, 15, 73-114.

Brunt, H. (2016). 'Stateless Stakeholders: Seen But Not Heard?' The Case of the Sama Dilaut in Sabah, Malaysia. M. A. dissertation, School of Global Studies, University of Sussex, Falmer, United Kingdom.

Citizenship a Privilege: NRD. (2015, 8 August). Daily Express Online. Retrieved 22 January 2019, from http://www.dailyexpress.com.my/news.cfm?NewsID=102168

Citizenship is a Special Privilege. (2012, 4 May). Daily Express Online. Retrieved 22 January 2019, from http://www.dailyexpress.com.my/news.cfm?NewsID=81388

Company Officer. (1886, 1 October). District Report. The British North Borneo Herald, p.221.

Company Officer. (1914). Simporna District. State of North Borneo, Annual Report on the East Coast Residency. Jesselton: Sabah State Archives.

Esscom Study on Pala'u Community. (2015, 21 March). Daily Express.

Gellner, E. (1983). Nations and Nationalism. Oxford: Basil Blackwell Pub. Limited.

Government Stuck with 300,000 Illegals. (2014, 5 January). Daily Express.

Hj. Mahali, S. N. (2012). Bajau Pantai Barat. Kuala Lumpur: Institut Terjemahan dan Buku Malaysia.

Hj. Mahali, S. N. (2013). The Sea People (Pala'u) in the Context of the Bajau Culture in Sabah. In Lai Y. M., G. A. Raman, S. N. Hj. Mahali, \& M. S. Esa (Eds.), Qasidah Tinta: Sebuah Festschrift untuk Prof. Emeritus Dr. Ahmat Adam (pp. 86116). Kota Kinabalu: Pusat Penataran Ilmu dan Bahasa.

Hassan, W. S. W., Idris, R. Z., \& Ahmad, S. A. (2010). Migration, Border Issues, Overlapping Claims and Citizenship. In R. Dambul, M. Azlima, \& S. Osman (Eds.), Sabah Priority Issues: Setting the Course for Change (pp. 87-102). Kota Kinabalu: Penerbit Universiti Malaysia Sabah.

Isin, E. F. (2008). Theorizing Acts of Citizenship. In E. F. Isin \& G. M. Nielsen (Eds.), Acts of Citizenship (pp. 15-43). London: Zed Books.

Lai, Y. M. (2015). Securing Sabah: Issues, Challenges and Responses. Journal of Public Security and Safety, 4(2), 59-78.

Malaysia Pays Cession Money, Not Lease to Sulu Sultanate. (2013). Mindanao Examiner.

More Deported with Cooperation of Manila Embassy. (2016, 30 January). Daily Express.

Nyers, P. (2008). No One is Illegal: Between City and Nation. In E. F. Isin \& G. M. Nielsen (Eds.), Acts of Citizenship (pp. 160-182). London: Zed Books.

Pallesen, A. K. (1985). Culture Contact and Language Convergence. Manila: Linguistic 
Society of the Philippines.

Population Growth - What Happens in Sabah and Sarawak? (2012). The Rocket. Retrieved 22 January 2018, from http://www.therocket.com.my/en/population-growth---what-happens-insabah-and-sarawak/

Proposal for UMS Study on Pala'u Community. (2014, 4 February). Daily Express. RCI Witness Urges Recognition of Bajau Palauh as Citizens. (2013, 6 February) Borneo Post online. Retrieved 16 April 2019, from https://www.theborneopost.com/2013/07/06/rci-witness-urgesrecognition-of-bajau-palauh-as-citizens/

Reddy, S. (2016, 6 September). Reels of Hope: A Young Filmmaker Is Speaking up for Underprivileged Children in Sabah through Her Work. The Star, p. 10.

Sabah is Our Home. (2013, 19 February). Free Malaysia Today. Retrieved 19 February 2016, from

http://www.freemalaysiatoday.com/category/nation/2013/02/19/'sabah-isour-home'/

Sadiq, K. (2005). When States Prefer Non-Citizens Over Citizens: Conflict Over Illegal Immigration into Malaysia. International Studies Quarterly, 49(1), 101-122.

Sadiq, K. (2009). Paper Citizens: How Illegal Immigrants Acquire Citizenship in Developing Countries. Oxford: Oxford University Press.

Sather, Clifford. 1997. The Bajau Laut: Adaptation, History, and Fate in a Maritime Fishing Society of Southeastern Sabah. Kuala Lumpur: Oxford University Press.

Social Technology Bureau. (2014). Sama-Bajau Reintegration Process and Social Intervention Strategies: Settling the Social Preparation Account. Quezon City: Department of Social Welfare and Development.

Some Village Heads, JKK Chairmen Not Reporting Presence of Illegal Immigrants. (2015, 13 July) Malay Mail. Retrieved 16 April 2019, from https://www.malaymail.com/news/malaysia/2015/07/13/some-villageheads-jkkk-chairmen-not-reporting-presence-of-illegalimmigran/932839

Sulu Leader of Lahad Datu Attack Dies. (2015, 14 January). The Star Online. Retrieved 23 January 2018, from https://www.thestar.com.my/news/nation/2015/01/14/sulu-kiram-dead/

Toyos, L. (2015, 5 February). Pala'u People Warned Not to Collude with Enemies. Daily Express. 